\title{
Giant Cell Tumor of Lumbar Spine Treated with RapidArc Intensity Modulated Arc Therapy: Case Report and Review of Literature
}

\author{
Eyad Fawzi Al Saeed', Mutahir A. Tunio², Stanciu Laura Gabriela' \\ ${ }^{1}$ Radiation Oncology Department, King Khalid University Hospital, King Saud University, Riyadh, \\ Saudi Arabia \\ ${ }^{2}$ Radiation Oncology Department, King Fahad Medical City, Riyadh, Saudi Arabia \\ Email: ealsaeed@yahoo.ca, drmutahirtonio@hotmail.com, lauragabrl@yahoo.com
}

Received 4 December 2013; revised 4 January 2014; accepted 12 January 2014

Copyright (C) 2014 by authors and Scientific Research Publishing Inc.

This work is licensed under the Creative Commons Attribution International License (CC BY). http://creativecommons.org/licenses/by/4.0/

(c) (7) Open Access

\section{Abstract}

Background: Giant cell tumors of the lumbar spine are rare and complete resection without major functional comprise is challenging despite advancements in spine surgery techniques. Radiation therapy has been an option in such cases; however there are high concerns for associated high small bowel toxicity and lack of dose escalation to achieve local control. With advent of intensity modulated radiation therapy (IMRT) it is now possible to give high radiation dose to tumor with minimal toxicity. Herein we present a rare case of giant cell tumor of fourth lumbar (L4) vertebra treated with RapidArc intensity modulated arc therapy (IMAT) with relevant review of literature. Methods: A 30-year-old female had low back pain for 6 months. She underwent surgical decompression at another hospital as having a L4-5 protruded intervertebral disc 2 months previously, but her back pain progressed with weakness of both legs with restricted movement. Radiological and pathological work-up confirmed the diagnosis of giant cell tumor of L4 vertebra. She refused further surgery and was referred to us for radiotherapy. Treatment plans for prescribed radiation dose of 59.4 Gy in 30 fractions were made by 3DCRT and RapidArc IMAT and comparison was made. Student's unpaired $t$ test was used to determine the significance of the difference between two plans in terms of dose to the tumor and small bowel. A $p$ value of 0.05 was considered statistically significant. Related literature was searched. Results: In RapidArc IMAT and 3DCRT plans mean doses to planning treatment volume (PTV) were 61.24 Gy (55.98 - 66.23) and 60.71 Gy (49.87 - 63.74) respectively (p 0.04) and mean doses to small bowel were found lesser in RapidArc plan [14.78 Gy (range: 0.39 - 53.15)] as compared to 3DCRT plan. Patient was started on RapidArc IMRT and she completed the course without any major sequelae. Conclusion: Lumbar spine giant cell tumors are rare and complete resection is often not possible. RapidArc IMAT is a feasible op- 
tion for such patients to deliver high dose radiation to achieve good local control with marked symptom relief and without severe toxicity.

\title{
Keywords
}

\author{
Giant Cell Tumor, Lumbar Vertebrae, Incomplete Resection, RapidArc, Intensity Modulated Arc \\ Therapy
}

\section{Introduction}

Giant cell tumors account for approximately 5\% of all primary bone tumors and about 20\% of benign bone tumors and axial skeleton (pelvis, spine and skull) is involved in $<10 \%$ of cases [1]. Giant cell tumors of spine above the sacrum are far rare and seen only in $1.8 \%-2.7 \%$ cases [2]. Unlike the peripheral skeleton, in lumbar spine a complete "en bloc" resection is always not possible without functional compromise even with novel spine surgery techniques and such cases are considered for postoperative radiotherapy to enhance local control [3]. However, in conventional radiotherapy era, only few patients with lumbar spine giant cell tumors have been treated because of documented low rates local control, increased small bowel toxicity, second malignancies and discrepancies in radiation doses [4]. In last two decades, intensity modulated radiation therapy (IMRT) has resolved these concerns and has shown that high median doses (55 - 64 Gy) can be delivered to achieve 77\% - 80\% local control in the absence of major acute and late sequelae [5].

RapidArc is a novel planning and delivery technique for intensity modulated arc therapy (IMAT) which consists of single arc where multi-leaf collimators (MLC), dose rate and gantry speed are optimized simultaneously to achieve the desired dose to tumor and adjacent critical structures [6].

Herein we present a rare case of giant cell tumor of fourth lumbar (L4) vertebra treated with RapidArc IMAT following an incomplete resection with relevant review of literature.

\section{Case Presentation}

A 30 year old Saudi woman had low back pain for 6 months. She had surgical decompression at another hospital as having a L4-5 protruded intervertebral disc two months previously, but her low backache persisted and she developed progressive weakness of both legs which caused her difficult to move. The patient was then admitted to our hospital for diagnostic and therapeutic evaluation. On neurological examination, there was severe tenderness over L4-L5 spine with straight leg raise (SLR) was positive bilaterally with weakness of dorsal and plantar movements (3/5) and absent ankle reflexes in both feet. The rest of examination was found normal. Magnetic resonance imaging showed a destructive lesion infiltrating the vertebral body of L4 vertebra with extension into pedicles bilaterally and encroachment upon neural foramina on left side where paraspinal component was extending into psoas muscle Figure 1. Radiological differential diagnosis was plasmacytoma or metastatic focus. Histopathology review of previous decompression biopsy confirmed the giant cell tumor. Patient was offered second "en bloc" surgery which she refused and she was referred to us for radiotherapy.

Due to previous subtotal resection, total dose of 59.4 Gy in 30 fractions (1.98 Gy per day) was prescribed. Two different plans were made (3DCRT and RapidArc IMAT) for comparative analysis. Student's double t test was used to determine the significance of the difference between two plans in terms of dose to the tumor and small bowel. The null hypothesis of no difference in dosimetry between two plans was tested. A $p$ value of 0.05 was considered statistically significant.

\section{Results}

\subsection{Dosimetric Characteristics}

Both 3DCRT and RapidArc plans were evaluated according to standard dose-volume histogram (DVH) of $\mathrm{D}_{95 \%}$ and $\mathrm{D}_{50 \%}$ which represented the doses of $95 \%$ and $50 \%$ PTV and conformity and homogeneity indices. The conformity index (CI) of the target volume was expressed as $\mathrm{CI}_{95 \%}=\left(\mathrm{PTV} 59.4 \mathrm{~Gy} / \mathrm{V}_{\mathrm{PTV}}\right) \times\left(\mathrm{PTV} \mathrm{V}_{59.4 \mathrm{~Gy}} / \mathrm{V}_{59.4 \mathrm{~Gy}}\right)$. The homogeneity index $(\mathrm{HI})$ of the target volume was defined as $\mathrm{HI}=100 \times\left[1-\left(\mathrm{D}_{5 \%}-\mathrm{D}_{95 \%}\right) / \mathrm{D}_{\text {mean }}\right]$. OARs, 


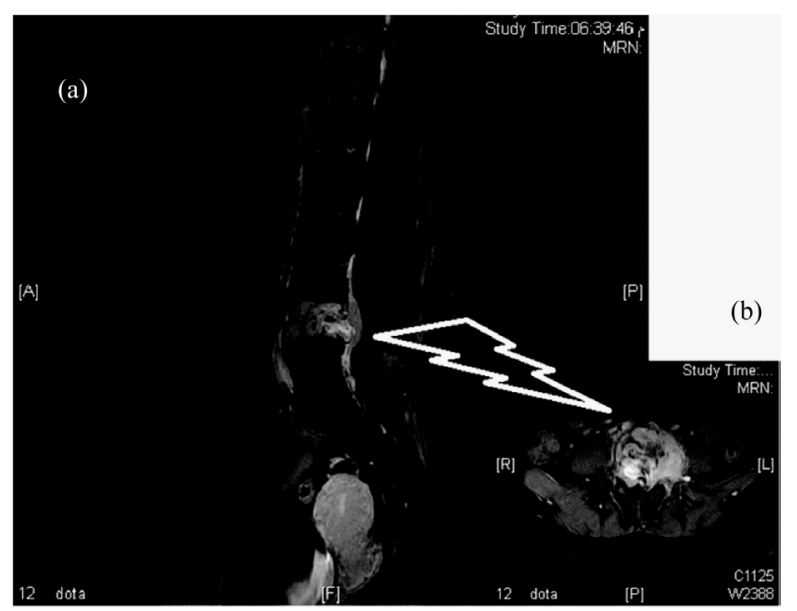

Figure 1. Magnetic resonance imaging (MRI) showing (a) a destructive lesion infiltrating the vertebral body of L4 vertebra (sagittal view) with (b) extension into pedicles bilaterally and encroachment upon neural foramina on left side with paraspinal component extension into psoas muscle (axial view).

$\mathrm{D}_{33 \%}, \mathrm{D}_{\text {mean }}, \mathrm{D}_{50 \%}$, and $\mathrm{D}_{66 \%}$ were adopted to evaluate the dose distribution of small bowel. RapidArc plan was found superior in terms of homogeneity and dose distribution to 3DCRT plan Figure 2.

\subsection{Dose-Volume Histogram (DVH) Characteristics}

Dose-volume histograms (DVH) data showed that mean dose to planning treatment volume (PTV) [volume; 686 $\mathrm{cm}^{3}$ ] was $61.24 \mathrm{~Gy}$ (55.98 - 66.23) in RapidArc and $60.71 \mathrm{~Gy}$ (49.87 - 63.74) in 3DCRT ( $p$ 0.04). Mean doses to small bowel [volume; $1916 \mathrm{~cm}^{3}$ ] was much less in RapidArc plan [14.78 Gy (0.39-53.15)] as compared to 3DCRT plan [17.42 Gy (2.7 Gy - 62.77)] ( $p$ 0.01) Figure 3 and Table 1.

\subsection{Quality Assurance (QA)}

After the using analytical anisotropic algorithm (AAA) system for dose calculation and Octavius phantom was used for quality control to ensure the pre-treatment accuracy and safety Figure 4, our patient was started according to RapidArc plan [7]. She completed the course without any major sequelae.

\subsection{Clinical Outcome}

At 12 months, patient was found pain free without any functional deficit. Repeat CT imaging at 6 months showed $25 \%$ reduction if tumor size.

\section{Discussion}

Lumbar spine giant cell tumors are rare and in most of the cases a complete "en bloc" resection is not feasible possible without major motor deficits and for this reason $50 \%$ of these patients recur locally [8]. Therefore radiotherapy has been considered as an alternative treatment for suchpatients; however delivery of high doses and sparing of adjacent critical organs is a real challenge for radiation oncologists [9]. To the best of our knowledge our patient is first case of L4 vertebral giant cell tumor that has been treated with RapidArc IMAT up to 59.4 Gy without any major bowel toxicity and with excellent local control.

RapidArc is novel IMRT delivery technique which is based on the IMAT or volumetric modulated arc therapy (VMAT) technique and it can obtain the similar dose distribution of the fixed IMRT. Main merits of RapidArc are the greater accuracy due to shorter time of complex IMRT delivery (less than 2.5 minutes) as compared to 3DCRT and fixed IMRT (7 - 9 minutes) and it has high reproducibility [10]. Shorter treatment time enhances the radiobiologic effect of radiation as Shibamoto et al., showed that between two fractions of radiotherapy, sub-lethal repair occurred in 2 - 3 minutes or longer time, while using breast cancer cell strain EMT 6 and head 


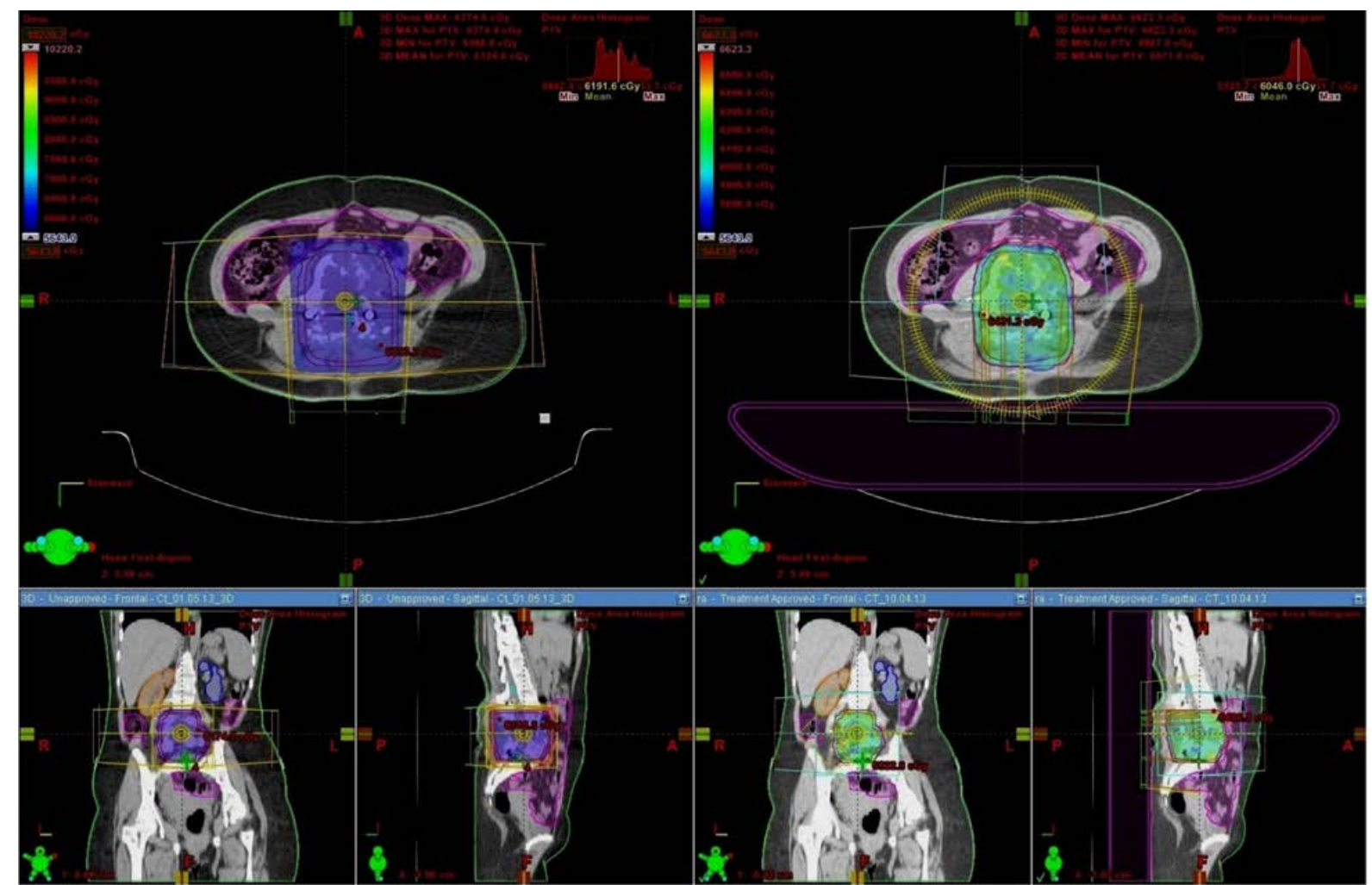

3D-Conformal treatment Plan

RapidArc IMAT plan

Figure 2. Comparison of dose distribution and homogeneity between RapidArc IMAT and 3DCRT plans showing superiority of RapidArc plans.

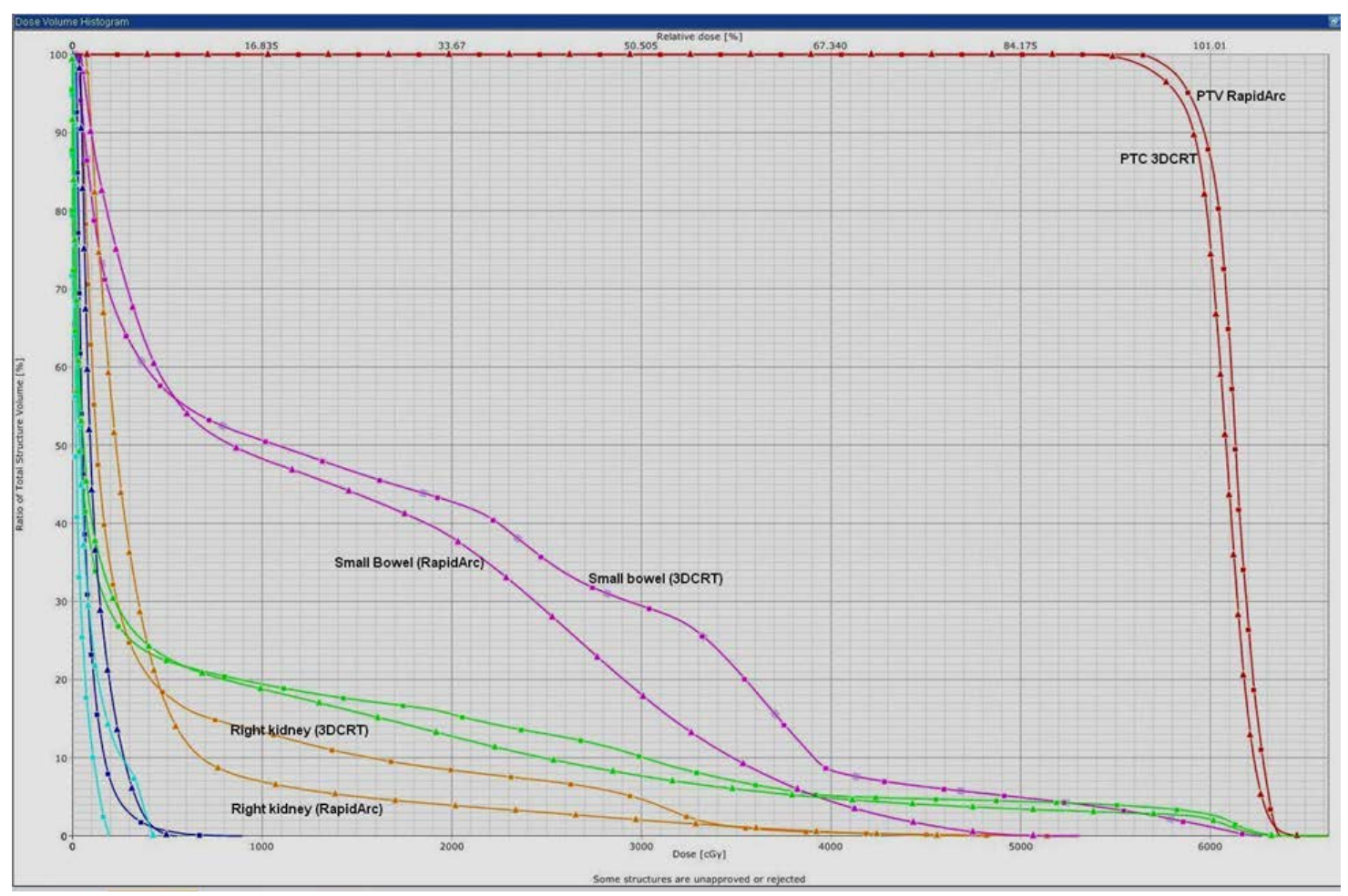

Figure 3. Comparative dose volume histograms of PTV, small bowel and organs at risks for RapidArc and 3DCRT plans. 




Figure 4. Pre-treatment RapidArc plan verification showing 99.8\% accuracy of plan tested on Octavius phantom.

Table 1. Dose distribution comparison of two treatment plans according to planning treatment volume (PTV) and organs at risk (OAR).

\begin{tabular}{cccc}
\hline Indices & RapidArc & 3DCRT & P value \\
\hline PTV D $D_{\text {mean }}(G y)$ & 61.24 & 60.71 & $\mathbf{0 . 4}$ \\
PTV D $D_{\text {max }}(G y)$ & 66.23 & 63.74 & $\mathbf{0 . 0 4}$ \\
PTV D $D_{\text {min }}(G y)$ & 55.98 & 49.87 & $\mathbf{0 . 0 4}$ \\
CI $_{95 \%}$ & 0.79 & 0.70 & $\mathbf{0 . 5}$ \\
HI & 80 & 0.71 & $\mathbf{0 . 4}$ \\
Small bowel $D_{\text {mean }}(G y)$ & 14.78 & 17.42 & $\mathbf{0 . 0 1}$ \\
Small bowel $D_{\text {min }}(G y)$ & 0.39 & 2.10 & $\mathbf{0 . 0 0 0 1}$ \\
Small bowel $D_{\text {max }}(G y)$ & 53.15 & 62.77 & $\mathbf{0 . 0 0 1}$ \\
Right kidney $D_{\text {mean }}(G y)$ & 0.41 & 4.71 & $\mathbf{0 . 0 0 1}$ \\
Left kidney $D_{\text {mean }}(G y)$ & 0.29 & 8.98 & $\mathbf{0 . 0 0 0 1}$ \\
Spinal cord $D_{\text {mean }}(G y)$ & 0.86 & 3.47 & $\mathbf{0 . 0 0 1}$ \\
Spinal cord $D_{\text {max }}(G y)$ & 4.3 & 19.2 & $\mathbf{0 . 0 0 1}$ \\
\hline
\end{tabular}

Abbreviations: $\mathrm{D}_{\max }=$ maximum dose, $\mathrm{D}_{\min }=$ minimum dose, $\mathrm{CI}=$ conformity index, $\mathrm{HI}=$ homogeneity index, $\mathrm{Gy}=\mathrm{Gray}$.

and neck squamous cell strain SCCVn of mice in vitro [11]. However treatment planning is time taking and needs vigorous quality check.

Due to rarity of spinal giant cell tumors and previously published data based on older radiation therapy techniques, there is no consensus on accepted fractionation or dose concept, yet few studies have shown that higher 
Table 2. Case reports of lumbar spine giant cell tumors treated with radiotherapy.

\begin{tabular}{|c|c|c|c|c|c|c|c|c|}
\hline $\begin{array}{l}\text { Author [Ref] } \\
\text { Date published }\end{array}$ & $\begin{array}{l}\text { Total } \\
\text { patients }\end{array}$ & $\begin{array}{l}\text { Lumbar spine } \\
\text { location (n) }\end{array}$ & Treatment & $\begin{array}{l}\text { RT doses to } \\
\text { lumbar spine }\end{array}$ & $\begin{array}{l}\text { Follow up } \\
\text { duration }\end{array}$ & $\begin{array}{l}\text { Clinical } \\
\text { outcomes (n) }\end{array}$ & $\begin{array}{l}\text { RT induced } \\
\text { neurological } \\
\text { deficit }\end{array}$ & $\begin{array}{c}\mathrm{RT} \\
\text { induced } \\
\text { sarcoma }\end{array}$ \\
\hline $\begin{array}{l}\text { Malone, S., et al. } \\
\quad \text { [4] } 1995\end{array}$ & 21 & 3 & $\mathrm{~S}+\mathrm{RT}(3)$ & 35 Gy & 15.4 years & $\begin{array}{l}\text { Major improvement (2) } \\
\text { Progressive symptoms (1) }\end{array}$ & None & None \\
\hline $\begin{array}{l}\text { Roeder, F., et al. } \\
\text { [5] } 2010\end{array}$ & 5 & 4 & $\begin{array}{c}\mathrm{E}+\mathrm{S}+\mathrm{RT}(1) \\
\quad \mathrm{RT}(3)\end{array}$ & $\begin{array}{l}60 \text { Gy (1) } \\
64 \text { Gy (2) } \\
66 \text { Gy (3) }\end{array}$ & $\begin{array}{l}35-63 \\
\text { months }\end{array}$ & $\begin{array}{l}\text { Major improvement (2) } \\
\text { No improvement (1) } \\
\text { Progressive symptoms (1) }\end{array}$ & None & None \\
\hline $\begin{array}{l}\text { Leggon, R.E., } \\
\text { et al. [8] } 2004\end{array}$ & 17 & 1 & $\mathrm{~S}+\mathrm{RT}(1)$ & 55 Gy & 63 months & Major improvement (1) & None & $1 / 17(11 \%)$ \\
\hline $\begin{array}{l}\text { Schwartz, L.H., } \\
\text { et al. [9] } 1989\end{array}$ & 13 & 1 & $\mathrm{~S}+\mathrm{RT}(1)$ & 54 Gy & 1.8 - 13 years & No improvement & None & None \\
\hline $\begin{array}{l}\text { Seider, M.J., et } \\
\text { al. [12] } 1986\end{array}$ & 15 & 1 & $\mathrm{~S}+\mathrm{RT}(1)$ & $66 \mathrm{~Gy}$ & $\begin{array}{l}23-99 \\
\text { months }\end{array}$ & Major improvement & None & None \\
\hline $\begin{array}{l}\text { Feigenberg, S.J., } \\
\text { et al. [13] } 2003\end{array}$ & 24 & 1 & $\mathrm{~S}+\mathrm{RT}(1)$ & $43 \mathrm{~Gy}$ & 20 years & Progressive symptoms & None & $\begin{array}{c}1 / 24 \\
(4.1 \%)\end{array}$ \\
\hline $\begin{array}{l}\text { Martin, C., et al. } \\
\text { [14] } 2010\end{array}$ & 23 & 13 & $\begin{array}{l}E+S(11) \\
S+R T(2)\end{array}$ & NM & 50.7 months & $\begin{array}{c}\text { Major improvement (6) } \\
\text { No improvement (3) } \\
\text { Progressive symptoms (4) }\end{array}$ & None & None \\
\hline
\end{tabular}

doses resulted in increased local control rates, as our patient was found disease free at one year [4] [5] [8] [9] [12]-[14]. There are two main concerns regarding radiotherapy treatment in lumbar giant cell tumors; first, few studies (Table 2) have shown the radiation induced malignant transformation and sarcoma induction in $4.1 \%$ $11 \%$ of patients, though these transformations could bethe part of disease biology itself in small proportion of patients as such transformations also have been documented in GCT who have not been treated with radiation therapy and use of conventional radiation therapy techniques in such patients [15]. Second, radiation induced myelopathy. Using conventional fractionation of 1.8 - $2 \mathrm{~Gy} /$ fraction to the full-thickness cord, the estimated risk of myelopathy is $<1 \%$ and $<10 \%$ at $54 \mathrm{~Gy}$ and $61 \mathrm{~Gy}$ respectively at alpha/beta ratio $(\alpha / \beta)$ of $0.87 \mathrm{~Gy}$ [16]. Dose escalation above 61 Gy with conventional radiotherapy or 3DCRT is not possible. New radiation therapy techniques, Rapid Arc or volumetric modulated arc therapy (VMAT) can produce high quality dose escalated treatment plans with high homogeneity/conformity indices and maximum adjacent spinal cord sparing [17].

\section{Conclusion}

In conclusion, lumbar spine giant cell tumors are rare and function-preserving surgery is not always possible. Such patients can be offered RapidArc IMAT which has shown excellent local control rate without any major acute and late sequelae. However, there is more need for reporting such cases treated with modern radiation therapy tools.

\section{Consent}

A formal written consent has been taken from patient for publication of this case report.

\section{Competing Interest}

Authors declare no potential conflict of interest. No financial or non-financial interests/grants were received for this case report.

\section{Authors Contribution}

EFA: Concept of study, manuscript editing;

SLG: medical physics data collection and verification;

MAT: manuscript writing, statistical analysis.

\section{References}

[1] Sanjay, B.K., Sim, F.H., Unni, K.K., et al. (1993) Giant-Cell Tumors of the Spine. The Bone \& Joint Journal, 75, 
148-154.

[2] Dahlin, D.C. (1977) Giant-Cell Tumor of Vertebrae above the Sacrum: A Review of 31 Cases. Cancer, 39, $1350-1356$. http://dx.doi.org/10.1002/1097-0142(197703)39:3<1350::AID-CNCR2820390351>3.0.CO;2-1

[3] Bennett, C.J., Marcus, R.B., Million, R.R., et al. (1993) Radiation Therapy for Giant Cell Tumor of Bone. International Journal of Radiation Oncology*Biology*Physics, 26, 299-304. http://dx.doi.org/10.1016/0360-3016(93)90210-M

[4] Malone, S., O’Sullivan, B., Catton, C., et al. (1995) Long-Term Follow up of Efficacy and Safety of Megavoltage Radiotherapy in High-Risk Giant Cell Tumors of Bone. International Journal of Radiation Oncology*Biology*Physics, 33, 689-694. http://dx.doi.org/10.1016/0360-3016(95)00159-V

[5] Roeder, F., Timke, C., Zwicker, F., et al. (2010) Intensity Modulated Radiotherapy (IMRT) in Benign Giant Cell Tumors-A Single Institution Case Series and a Short Review of the Literature. Radiation Oncology, 5, 18. http://dx.doi.org/10.1186/1748-717X-5-18

[6] Otto, K. (2008) Volumetric Modulated Arc Therapy: IMRT in a Single Gantry Arc. Medical Physics, 35, 310-317. http://dx.doi.org/10.1118/1.2818738

[7] Korreman, S., Medin, J. and Kjer Kristofferson, F. (2009) Dosimetric Verification of Rapid Arc Treatment Delivery. Acta Oncologica, 48, 185-191. http://dx.doi.org/10.1080/02841860802287116

[8] Leggon, R.E., Zlotecki, R., Reith, J., et al. (2004) Giant Cell Tumor of the Pelvis and Sacrum. Clinical Orthopaedics and Related Research, 423, 196-207. http://dx.doi.org/10.1097/01.blo.0000128643.38390.07

[9] Schwartz, L.H., Okunieff, P.G., Rosenberg, A., et al. (1989) Radiation Therapy in the Treatment of Difficult Giant Cell Tumors. International Journal of Radiation Oncology*Biology*Physics, 17, 1089-1095. http://dx.doi.org/10.1016/0360-3016(89)90160-0

[10] Thieke, C., Kufer, K.H., Monz, M., et al. (2007) A New Concept for Interactive Radiotherapy Planning with MultiCriteria Optimization: First Clinical Evaluation. Radiotherapy and Oncology, 85, 292-298. http://dx.doi.org/10.1016/j.radonc.2007.06.020

[11] Shibamoto, Y., Ito, M., Sugie, C., et al. (2004) Recovery from Sublethal Damage during Intermittent Exposures in Cultured Tumor Cells: Implications for Dose Modification in Radiosurgery and IMRT. International Journal of Radiation Oncology*Biology*Physics, 59, 1484-1490. http://dx.doi.org/10.1016/j.ijrobp.2004.04.039

[12] Seider, M.J., Rich, T.A., Ayala, A.G., et al. (1986) Giant Cell Tumor of Bone: Treatment with Radiation Therapy. Radiology, 161, 537-540.

[13] Feigenberg, S.J., Marcus, R.B., Zlotecki, R.A., et al. (2003) Radiation Therapy for Giant Cell Tumors of Bone. Clinical Orthopaedics and Related Research, 411, 207-216. http://dx.doi.org/10.1097/01.blo.0000069890.31220.b4

[14] Martin, C. and McCarthy, E.F. (2010) Giant Cell Tumor of the Sacrum and Spine: Series of 23 Cases and a Review of the Literature. Iowa Orthopaedic Journal, 30, 69-75.

[15] Kay, R.M., Eckardt, J.J., Seeger, L.L., et al. (1994) Pulmonary Metastasis of Benign Giant Cell Tumor of Bone: Six Histologically Confirmed Cases Including One of Spontaneous Regression. Clinical Orthopaedics and Related Research, 302, 219-230.

[16] Kirkpatrick, J.P., van der Kogel, A.J. and Schultheiss, T.E. (2010) Radiation Dose-Volume Effects in the Spinal Cord. International Journal of Radiation Oncology*Biology*Physics, 76, S42-49. http://dx.doi.org/10.1016/j.ijrobp.2009.04.095

[17] Wu, Q.J., Yoo, S., Kirkpatrick, J.P., et al. (2009) Volumetric Arc Intensity-Modulated Therapy for Spine Body Radiotherapy: Comparison with Static Intensity-Modulated Treatment. International Journal of Radiation Oncology*Biology *Physics, 75, 1596-604. http://dx.doi.org/10.1016/j.ijrobp.2009.05.005 